Received: $22-06-2020$

Revised: 06-10-2020

Published: 31-10-2020

\title{
ANALISIS KEMAMPUAN BERPIKIR KREATIF PESERTA DIDIK PADA MATERI PERBANDINGAN
}

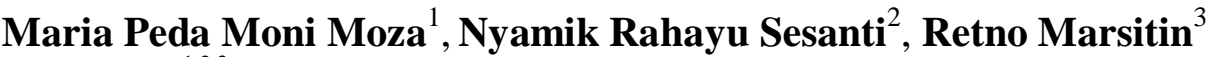 \\ ${ }^{1,2,3}$ Pendidikan Matematika, Universitas Kanjuruhan Malang \\ ${ }^{1}$ mariapedamonimoza@gmail.com \\ 2 nyamik@unikama.ac.id \\ ${ }^{3}$ mars_retno@unikama.ac.id
}

\begin{abstract}
Abstrak: Jenis Penelitian ini adalah penelitian deskriptif kualitatif yang bertujuan untuk menganalisis kemampuan berpikir kreatif peserta didik pada materi perbandingan. Subjek penelitian terdiri atas 28 peserta didik kelas VII-2 SMP Negeri 23 Malang. 6 peserta didik diambil untuk dianalisis, terdapat kesamaan jawaban di setiap tingkatannya. Pengumpulan data dilakukan dengan tes, wawancara, dan dokumentasi. Uji keabsahan data dilakukan dengan teknik triangulasi metode. Data dianalisis dengan tahapan reduksi data, penyajian data dan penarikan kesimpulan. Hasil penelitian ini yaitu pada kriteria kurang kreatif atau Tingkat Kemampuan Berpikir Kreatif (TKBK) dengan 39,28\%, dan kriteria tidak kreatif dengan 60,71\%. Kriteria sangat kreatif, kreatif dan cukup kreatif tidak ditemukan subjek pada tingkatan ini. Berdasarkan hasil penelitian ini diperoleh kemampuan berpikir kreatif dengan kriteria kurang kreatif, peserta didik mampu memahami soal, memberikan ide, memberikan lebih dari satu jawaban dan menjawab tetapi belum ada unsur kebaruan. Peserta didik dengan kriteria tidak kreatif terdapat 17 orang, peserta didik mampu memahami soal, memberikan ide, memberikan satu jawaban walaupun kurang lengkap dan menjawab tetapi belum ada unsur kebaruan.
\end{abstract}

Kata Kunci: Open-Ended; Kemampuan Berpikir Kreatif.

Abstract: This research with type of descriptive qualitative research that aims to analyze students' creative thinking skills on comparison material. The study subjects consists 28 students of class VII-2 of SMP Negeri 23 Malang, then 6 students were taken for analysis, because there were the same answers at each level. Data collection is done by tests, interviews, and documentation. Data validity test is done by the method triangulation technique. Data were analyzed with the stages of data reduction, data presentation and conclusion drawing. The results of this study are the criteria for the lack of creative or Creative Thinking Ability Level (TKBK) with $39.28 \%$, and the criteria of not creative with $60.71 \%$. Very creative criteria, creative and quite creative there are no subjects found at this level. Conclusions based on the results of this study obtained the ability to think creatively with less creative criteria, students are able to understand questions, give ideas, give more than one answer and answer but there is no novelty element. Students with creative criteria there are 17 people, students are able to understand questions, give ideas, give one answer even though it is incomplete and answer but there is no novelty element.

Keywords: Open-Ended;Creative Thinking Skills.

\section{Pendahuluan}

Analisis kemampuan berpikir kreatif amat dibutuhkan dalam mengukur tingkat kreativitas seseorang dalam menyelesaikan permasalahan yang diberikan (Y.N Firdaus, dkk: 2018). Lindren (dalam Yamin, 2013) berpikir kreatif yaitu memberikan kemungkinan jawaban atau pemecahan masalah dan mencetuskan banyak gagasan. Tingkat kreatifitas peserta didik bisa ditumbuhkan dengan berbagai metode, salah satunya dengan pemilihan cara pengajaran yang tepat oleh guru. Kreatifitas peserta didik terlihat dari proses peserta didik mengerjakan setiap masalah yang diberikan. Hal ini dapat dilihat cara peserta didik dalam memecahkan soal matematika dengan banyak metode yang lain namun tidak bertolak belakang 
dengan prosedur sebelumnya (Alhabbah, 2015). Munandar (2012) memberi pendapat bahwa berpikir kreatif bisa dinyatakan sebagai indikator kelancaran, keluwesan, orisinalitas dan ketrampilan terperinci. Observasi peneliti di SMP Negeri 23 Malang pada kelas VII, lebih dari 30\% peserta didik (berdasarkan KKM yaitu 70) sehingga peserta didik belum memenuhi kriteria (TKBK). Jawaban peserta didik atau hasil akhir sudah benar tetapi mereka belum mampu membuat alternatif cara yang berbeda, jawaban yang diberikan peserta didik masih sama dengan contoh yang guru berikan. Peserta didik banyak yang menyelesaikan soal dengan cara seperti di atas terdapat $83 \%$ dari 12 peserta didik, dengan demikian dapat dikatakan bahwa TKBK peserta didik termasuk dalam tingkat kurang kreatif, karena hampir semua peserta didik menggunakan satu cara/alternatif dalam menyelesaikan soal dan sama sekali tidak ada kebaruan.

TKBK peserta didik dikatakan kreatif apabila peserta didik mampu mengerjakan persoalan yang menghasilkan penyelesaian maupun metode yang berbeda, dengan meningkatkan potensi kreatifitas peserta didik maka aktivitas belajar dalam menjawab persoalan dengan berbagai solusi dan penyelesaian benar sehingga memacu kemampuan cendekiawan serta pengetahuan peserta didik saat mendapatkan sesuatu hal baru. Pengajaran yang menyajikan masalah terbuka atau berbagai penyelesaian yang benar disebut pengajaran dengan pendekatan Open-ended. Open-ended mampu memicu potensi kreatifitas peserta didik karena peserta didik diberikan permasalahan terbuka yang memberi kebebasan bagi peserta didik untuk mengatasi suatu permasalahan yang sudah diteliti oleh peneliti sebelumnya dalam mengetahui potensi kreatifitas saat proses pembelajaran
(Priyogo, 2014). Penelitian ini bermaksud menganalisis kemampuan berpikir kreatif peserta didik pada materi perbandingan.

\section{Metode Penelitian}

Penelitian ini adalah jenis penelitian deskriptif. Lokasi penelitian adalah SMP Negeri 23 Malang. Sumber data diperoleh dari hasil jawaban soal tertulis kemampuan berpikir kreatif dan hasil tanya jawab peserta didik di kelas VII-2 yang terdiri dari 28 orang. Peneliti memilih 6 orang peserta didik untuk diteliti. Hal ini berdasarkan keterbatasan waktu dalam penelitian dan kriteria Tingkatan Kemampuan Berpikir Kreatif (TKBK) yaitu 3 orang untuk tingkat kurang kreatif dan 3 orang untuk tingkat tidak kreatif.

\section{Hasil dan Pembahasan}

Tahapan analisis mencakup reduksi data, proses penyajian data dan proses kesimpulan. Sebelum pengambilan data, instrumen divalidasi oleh dua orang validator yaitu dosen matematika UNIKAMA dan bapak guru matematika di SMP Negeri 23 Malang. Berdasarkan validasi instrumen oleh validator pertama, soal yang dibuat oleh peneliti dalam kategori baik. Validator memberikan beberapa saran dan komentar terhadap instrumen yang diajukan. Kesimpulan dari hasil validasi pertama dengan sedikit revisi. Hasil validasi dari validator kedua, soal yang dibuat oleh peneliti dalam kategori baik. Kesimpulan dari hasil validator kedua bahwa tanpa revisi.

Berdasarkan analisis data yaitu peserta didik yang berada pada kriteria tidak kreatif menduduki paling tinggi adalah 17 peserta didik dan 11 peserta didik pada kriteria kurang kreatif. Pada kriteria kurang kreatif atau TKBK 1 terdapat 11 peserta didik atau mencapai $39,28 \%$, dan kriteria tidak kreatif atau TKBK 0 terdapat 17 peserta didik atau mencapai $60,71 \%$. Pada kriteria sangat

Pi: Mathematics Education Journal 
kreatif, kreatif dan cukup kreatif atau tidak ditemukan subjek pada tingkatan ini.

\section{A. Tingkat Kemampuan Berpikir Kreatif (TKBK) 1}

Pada kategori kurang kreatif terdapat 3 subjek yaitu AYF, SAPA dan NMP. Dari ketiga subjek, peneliti memilih subjek SAPA mewakili kategori kurang kreatif untuk dianalisis. Hasil tes berpikir kreatif subjek SAPA adalah 52,7. Berdasarkan persentase hasil tes SAPA masuk pada kategori kurang kreatif.

1) Soal nomor 1

Perbandingan uang Wahid dan uang Dina yaitu 1: $x$. Apabila perbedaan uang mereka Rp.120.000,00. Berapakah jumlah uang mereka dengan menentukan nilaix terdahulu (buatlah lebih dari dua jawaban).

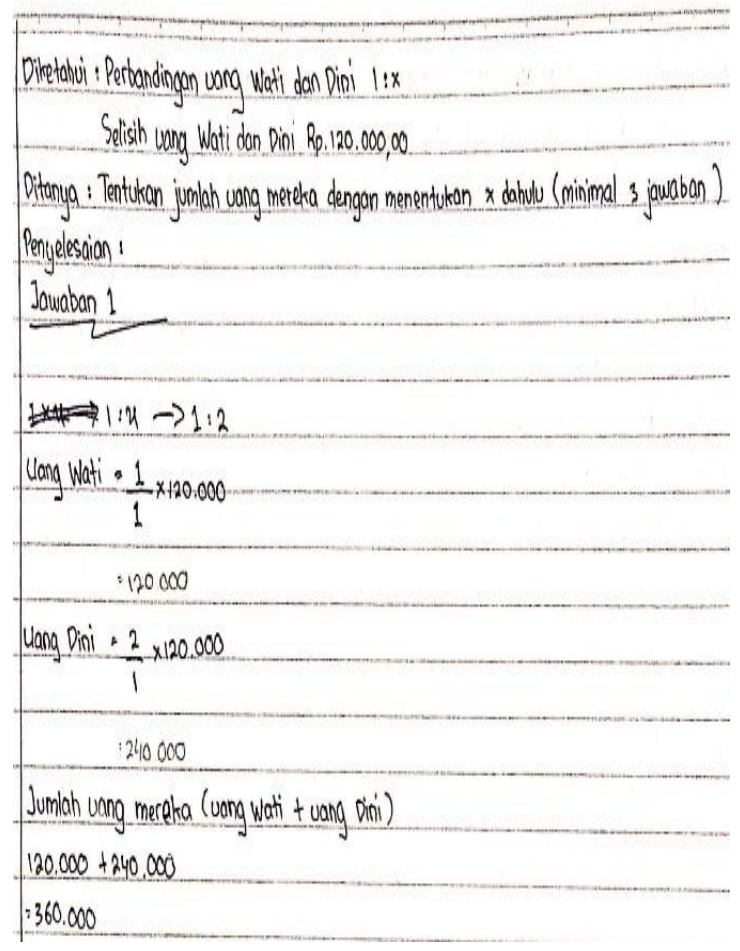

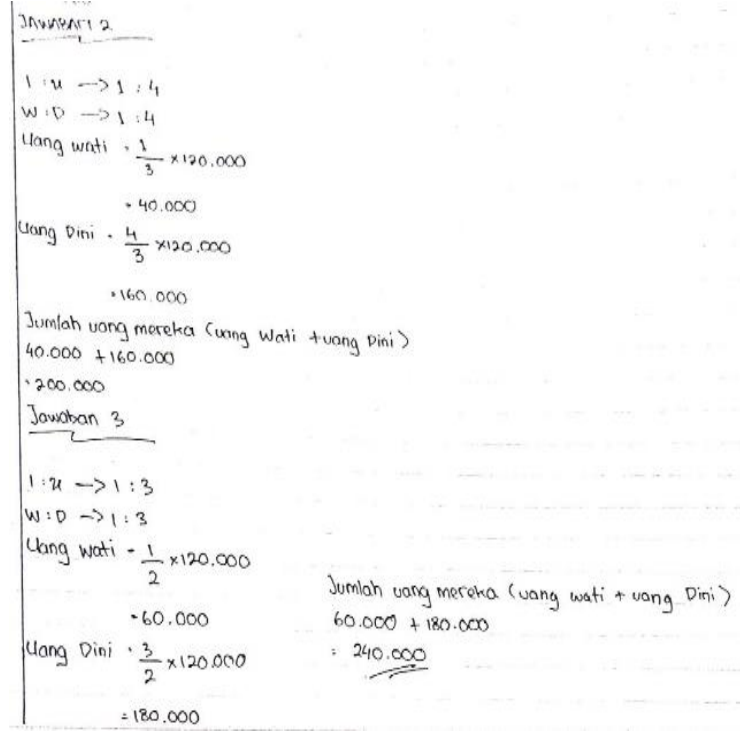

Gambar 1. Hasil tes subjek SAPA soal nomor 1

Pada soal nomor 1 SAPA memperoleh skor 9, indikator kelancaran memperoleh skor 4 yang berarti lebih dari satu ide yang relevan dan pemecahan masalah lengkap dan jelas. Hal ini sesuai dengan pendapat Liliawati dan Puspita (2010:426) mengemukakan kelancaran (fluency) yaitu menjawab dengan lancar mengungkapkan gagasan-gagasannya dan dengan cepat melihat kesalahan dan kelemahan. Indikator keluwesan skor 4 berarti tiga jawaban perhitungan benar dan hasil benar. Hal ini sependapat dengan Sesanti \& Marsitin (2018) mengutarakan bahwa"Flexibility refer to Children can generate ideas, answers, variations, and have the ability to see a problem from different perspective". Keluwesan mengacu pada anak-anak bisa menghasilkan ide-ide, jawaban, variasi dan memiliki kemampuan untuk melihat masalah dari perspektif yang berbeda. Pada indikator kebaruan SAPA memperoleh skor 1 berarti SAPA memberikan jawaban tapi belum ada unsur kebaruan.

2) Soal nomor 2

Untuk mengerjakan suatu proyek selama 72 hari dibutuhkan 24 tenaga kerja. Selesai dikerjakan 30 hari proyek

Pi: Mathematics Education Journal 
diistirahatkan selama $y$ hari. Tentukan banyak tenaga kerja yang perlu ditambah supaya proyek selesai tepat waktu dengan menentukan nilai $y$ terdahulu (buatlah lebih dari dua jawaban)

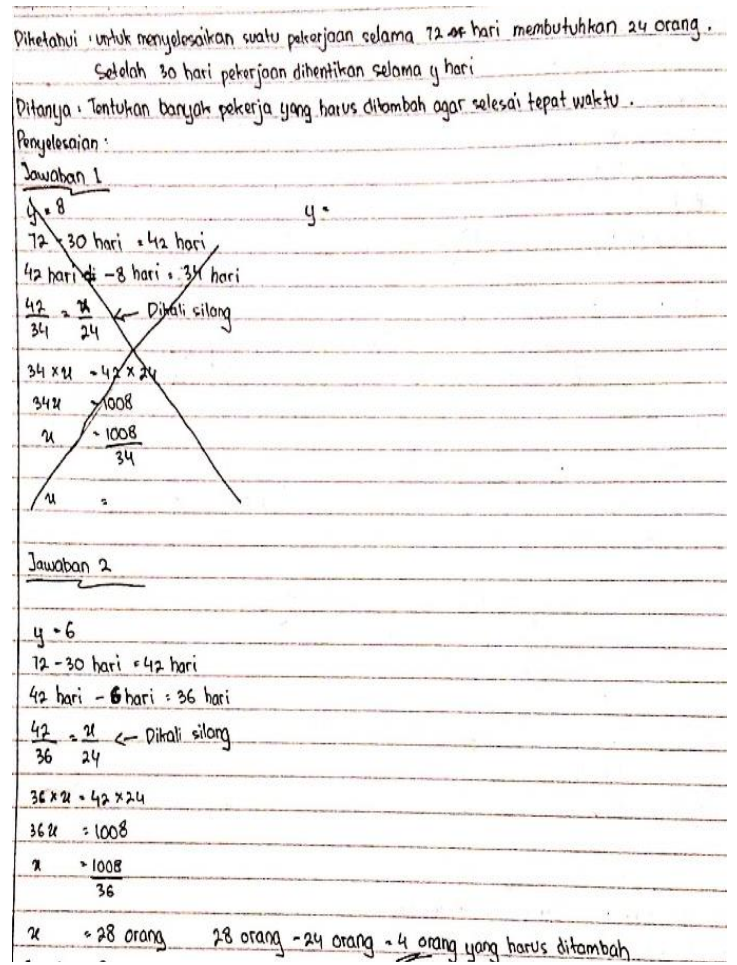

Gambar 2. Hasil tes subjek SAPA soal nomor 2

Soal nomor 2 SAPA memperoleh skor 5, indikator kelancaran memperoleh skor 2 yang berarti SAPA memberikan ide yang relevan dan pengungkapannya lengkap dan jelas 50\%. Indikator keluwesan skor 2 berarti satu jawaban cara benar dan hasil benar. Pada indikator kebaruan SAPA memperoleh skor 1 berarti SAPA memberikan jawaban tapi belum ada unsur kebaruan.

3) Soal nomor 3

Seorang gembala memiliki stok makanan untuk 30 ekor kambing selama 15 hari. Apabila gembala tersebut menjual $x$ ekor kambing, Berapa hari stok makanan tersebut akan habis dengan menentukan nilai $x$ terdahulu (buatlah lebih dari dua jawaban)

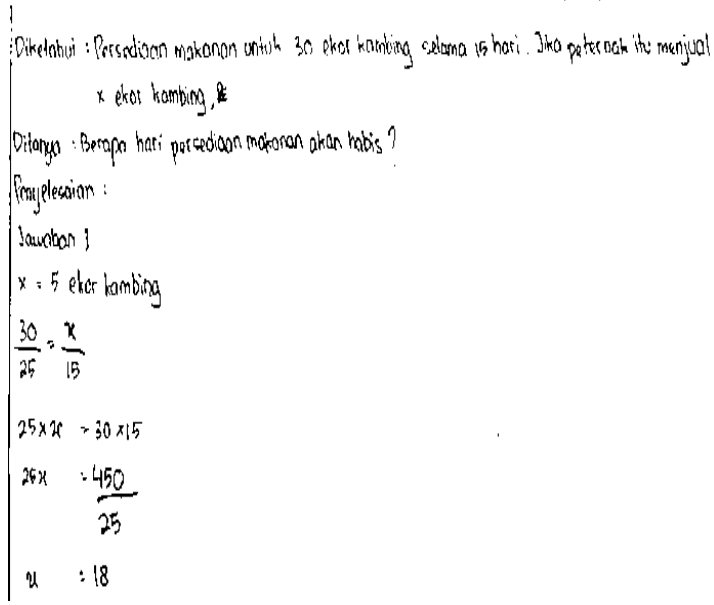

Gambar 3. Hasil tes subjek SAPA soal nomor 3

Soal nomor 3 SAPA memperoleh skor 5, indikator kelancaran memperoleh skor 2 yang berarti memberikan ide yang relevan dan pengungkapannya lengkap dan jelas $50 \%$. Indikator keluwesan skor 2 berarti SAPA menjawab dengan satu penyelesaian, cara dan hasil pengerjaan benar. Pada indikator kebaruan SAPA memperoleh skor 1 berarti SAPA memberikan jawaban tetapi belum ada unsur kebaruan. Hal ini sesuai dengan hasil wawancara peneliti bersama SAPA mampu memahami soal, SAPA memberikan ide walaupun SAPA menjawab tiap soal tidak lebih dari dua jawaban dan belum mampu menjawab soal dengan caranya sendiri.

\section{B. Tingkat Kemampuan Berpikir Kreatif (TKBK) 0}

Pada TKBK 0 atau yang termasuk kategori tidak kreatif terdapat 3 subjek yaitu SSW, DHAD dan RRP. Dari ketiga subjek, peneliti memilih subjek SSW mewakili kategori kurang kreatif untuk dianalisis. Hasil tes berpikir kreatif subjek SSW adalah 16,6. Berdasarkan persentase hasil tes SSW masuk pada kategori tidak kreatif.

1) Soal nomor 1

Perbandingan uang Wahid dan uang Dina yaitu 1: $x$. Apabila pebedaan uang mereka Rp.120.000,00. Berapakah jumlah uang mereka dengan menentukan nilaix 
terdahulu (buatlah lebih dari dua jawaban).

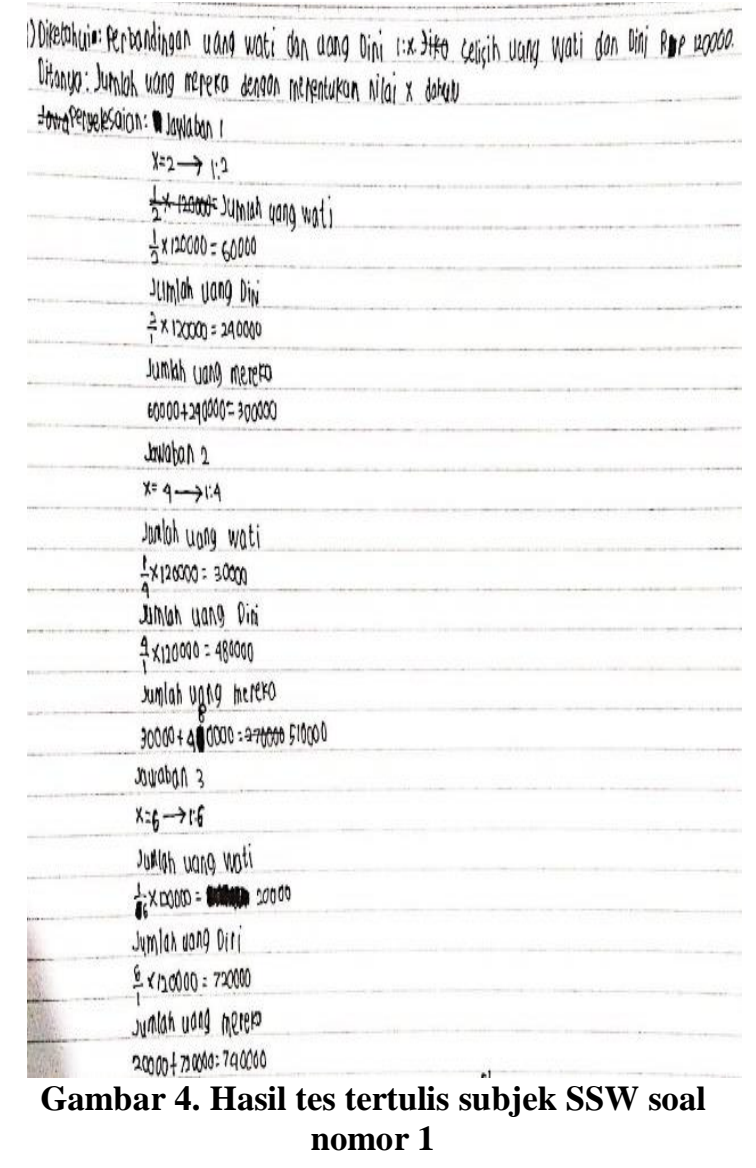

Pada soal nomor 1 SSW memperoleh skor 5, indikator kelancaran skor 2 yang berarti ide yang relevan dan pengungkapannya lengkap dan jelas $50 \%$. Indikator keluwesan memperoleh skor 1 berarti SSW memberikan tiga jawaban namun hasil salah. Pada indikator kebaruan SSW memperoleh skor 1 berarti SSW memberikan jawaban tapi belum ada unsur kebaruan. Hal ini sesuai dengan pendapat Silver (dalam Siswono 2011) kebaruan (novelty) berarti peserta didik mampu memberikan jawaban dengan satu cara yang tidak biasa dilakukan oleh peserta didik pada tingkat pengetahuannya.

2) Soal nomor 2

Untuk mengerjakan suatu proyek selama 72 hari dibutuhkan 24 tenaga kerja. Selesai dikerjakan 30 hari proyek diistirahatkan selama $y$ hari. Tentukan banyak tenaga kerja yang harus ditambah supaya proyek selesai tepat waktu dengan menentukan nilai $y$ terdahulu (buatlah lebih dari dua jawaban)

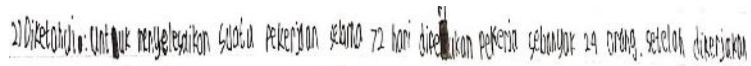

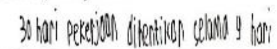

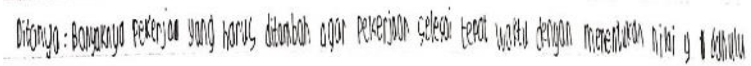

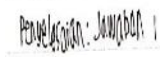

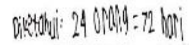

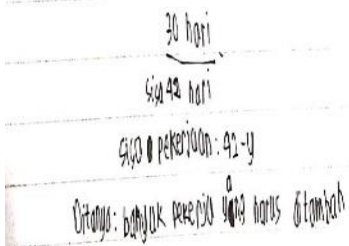

Gambar 5. Hasil tes tertulis subjek SSW soal nomor 2

Soal nomor 2 SSW memperoleh skor 1, indikator kelancaran memperoleh skor 1 yang berarti sebuah ide yang relevan dan pengungkapannya $25 \%$. Indikator keluwesan memperoleh skor 0 berarti subjek belum mampu memberikan jawaban. Indikator kebaruan memperoleh skor 0 berarti SSW tidak memberikan jawaban.

3) Soal nomor 3

Seorang gembala memiliki stok makanan untuk 30 ekor kambing selama 15 hari. Apabila gembala tersebut menjual $x$ ekor kambing, Berapa hari stok makanan tersebut akan habis dengan menentukan nilai $x$ terdahulu (buatlah lebih dari dua jawaban)

Soal nomor 3 SSW memperoleh skor 0 , subjek tidak menjawab soal nomor 3 sehingga skor yang diperoleh masing-masing indikator adalah 0 . Hal ini sesuai dengan hasil wawancara SSW mampu memahami soal, memberikan ide dengan jawaban kurang lengkap. Hal ini sejalan dengan pendapat Philip (dalam Putri 2018) kemampuan berpikir kreatif tidak dapat dipaksakan, akan tetapi harus dikembangkan. Kebiasaan berpikir 
kreatif bisa dilakukan sebagai cara menumbuhkan kemampuan berpikir kreatifitas dalam menyelesaikan masalah. Sesanti \& Marsitin (2017) menyatakan bahwa berpikir kreatif anak tercapai terlihat dari bagaimana anak mengatasi setiap persoalan yang dihadapi. Hal ini dapat dilihat dari bagaimana cara peserta didik menyelesaikan masalah.

\section{Kesimpulan}

Kesimpulan penelitian bahwa peserta didik dengan kriteria kurang kreatif atau TKBK 1 terdapat 11 orang, peserta didik mampu memahami soal, memberikan ide, mengerjakan lebih dari satu penyelesaian dan menjawab tetapi tidak ada unsur kebaruan. Peserta didik dengan kriteria tidak kreatif TKBK 0 terdapat 17 orang, peserta didik mampu memahami soal, memberikan ide, memberikan satu jawaban walaupun kurang lengkap dan menjawab tetapi belum ada unsur kebaruan.

\section{Daftar Rujukan}

Anna Verlita Yesi Herwanti. 2018. Motivasi dan Hasil Belajar Peserta didik Materi Perbandingan dengan Menggunakan Model Pembelajaran Kooperatif tipe Numbered Head Together di Kelas VII A SMP Bopkri 1 Yogyakarta Tahun Ajaran $2017 / 2018$.

Asdarin. 2011. Pembelajaran Materi Bangun Ruang dengan Pendekatan Problem Posing Untuk Meningkatkan Berpikir Kreatif Peserta didik Kelas VIII SMP Negeri 6 RSBI Banda Aceh, skripsi, (Banda Aceh; Universitas Syiah Kuala, 2011), h. 20-21. 11

Darminto, B.P (2010). Peningkatan Kreativitas dan Pemecahan Masalah bagi Calon Guru Matematika melalui pembelajaran Treffiger,
[Online]

Tersedia:

http://eprint.uny.ac.id/10500/1/p12-

Bambang\%20Priyo.pdf.

Desember 2016]

Fardah, DK 2012. Analisis Proses dan Kemampuan Berpikir Kreatif Peserta didik dalam Matematika melalui Tugas Open Ended (Online). Tersedia:

http://feryferdiansyah16.blogspot.co. id/2012/11/berpikirkreatif-

matematis.html?m=1 diakses pada 6 Februari 2018

Ghony, M. Djunaidi dan Almanshur, Fauzan, 2012. Metodologi Penelitian Kualitatif. Jogjakarta: Ar-Ruzz Media.

Mochammad Ali Aziz Alhabbah. 2015. Analisis Berpikir Kreatif dalam Menyelesaikan Soal Luas Bangun Datar Peserta didik Kelas VII-G MTsN Karangrejo Tulungagung. Disertasi tidak diterbitkan.

Tulungagung: IAIN

Munandar, U. 2009. Pengembangan Kreativitas Anak Berbakat. Jakarta: Rineka Cipta.

Sesanti, N.R., \& Marsitin, R. 2017. Analysis of Creative Thinking Ability of Primary School Department Student on Proposing Mathematics Problem. Advances in Social Science, Education and Humanities Research (ASSEHR), 160, 49-53.

Priyogo, wahyu. 2014. "Pengaruh Pendekatan Open Ended Terhadap Kemampuan Berpikir Kreatif Matematis Peserta didik”. Skripsi Jurusan Pendidikan Matematika Fakultas Ilmu Tarbiyah dan Keguruan Universitas Islam Negeri Syarif Hidayatullah Jakarta. 
Shimada. 1997. The Significance of An Open-Ended Approach (Virginia: National Council of Theachers Mathematics, 1997), h. 1. Suryadi. 2017. Penerapan Pendekatan Open Ended Pada Pembalajaran Matematika untuk Meningkatan Kemampuan Berpikir Kreatif peserta didik SMPN 4 Banda Aceh.

Sugiyono, (2012). Memahami Penelitian Kualitatif Bandung: ALFABETA.

Sumarmo, U. (2010). Teori, Paradigma, Prinsip, dan Pendekatan Pembelajaran MIPA dalam Konteks Indonesia. Bandung: FPMIPA UPI.

Wijaya \& Ariyadi. 2012. Pendidikan matematika Realistik. Yogyakarta: Graha Ilmu.
Y. N. Firdausi, dkk. 2018. Analisis Kemampuan Berpikir Kreatif Peserta didik Ditinjau dari Gaya Belajar pada Pembelajaran Model Eliciting Activities (MEA). (Online) http://journal.unnes.ac.id/sju/index.p $\mathrm{hp} / \mathrm{prisma} /$ article/download/19582/95 $\underline{12}$ diakses pada 6 Februari 2018

Yamin, M. (2013). Strategi dan Metodedalam Model Pembelajaran. Jakarta: Referensi GP Press Group.

Yatim Riyanto. 2010. Paradigma Baru Pembelajaran, (Jakarta: Kencana, 2010), h. 229 